\title{
ANALISIS KELAYAKAN PENGEMBANGAN USAHA TEPUNG MOCAF DALAM MENINGKATKAN TARAF HIDUP MASYARAKAT DI DESA KENANGA LIWA LAMPUNG BARAT
}

\author{
Sri Haryanti ${ }^{(1)}$, Yuliana Yamin ${ }^{(2)}$, Maria Elina ${ }^{(3)}$ \\ Fakultas Ekonomi Universitas Sang Bumi Ruwa Jurai \\ sri_haryanti30@gmail.com,yuliana.yamin@fe.saburai.ac.id,maria.elina@fe.saburai.ac.id
}

\begin{abstract}
Abstrak. Salah satu modifikasi tepung ubikayu yang memiliki nilai jual yang cukup tinggi adalah tepung Mocaf. Tepung Mocaf merupakan singkatan dari (Modified Cassava Flour). Sederhananya adalah tepung dari singkong yang telah dimodifikasi dengan cara difermentasi. Dengan cara ini, aroma singkong menjadi hilang. Keunggulan dari tepung mocaf adalah kandungan kalsium dalam tepung mocaf yang lebih tinggi dari gandum maupun padi. Hasil penelitian didapatkan bahwa proses pengolahan tepung mocaf diawali dengan sortasi ubi yang akan diolah kemudian dilanjutkan dengan pengupasan kulit ubi kayu. Ubi yang baru selesai dikupas langsung direndam dalam air lalu dicuci sebanyak 2 kali agar bersih dari kotoran yang menempel saat pengupasan. Selanjutnya dicacah dengan menggunakan mesin perajang ubi. Hasil cacahan kemudian difermentasi dengan cara perendaman dalam air yang telah dicampur dengan starter Bimo CF selama 12-15 jam untuk mengubah struktur ubi kayu sehingga dapat mengurangi aroma dan rasa pahit ubi kayu. Selain itu juga untuk meningkatkan kecerahan warna tepung. Hasil dari penelitian ini agroindustri pengolahan tepung mocaf sangat layak untuk diusahakan. Saran yang penulis sampaikan hendaknya pemerintah daerah lebih memperhatikan pengembangan usaha tepung mocaf di Desa Kenanga Liwa Kabupaten Lampung Barat agar taraf hidup masyarakat setempat dapat menjadi lebih baik. Hendaknya pihak pemerintah dan swasta dapat memberikan modal / pinjaman agar dapat mengembangkan usaha tepung mocaf di daerah Desa Kenanga Liwa Kabupaten Lampung Barat.
\end{abstract}

Kata kunci: Kelayakan, Pengembangan, Tepung, Usaha.

\section{PENDAHULUAN}

Sektor pertanian merupakan sektor yang cukup penting bagi Indonesia. Sektor ini memberikan kontribusi terhadap PDB (Produk Domestik Bruto), penyerapan lapangan pekerjaan, ketersediaan sumber makanan, dan meningkatkan nilai devisa negara melalui ekpor (Suratiyah, 2008). Sektor pertanian memberikan kontribusi terhadap PDB (Produk Domestik Bruto) Indonesia mencapai $13,6 \%$ setiap tahunnya. Menurut data dari Badan Pusat Statistik pada kuartal pertama tahun 2018, sektor pertanian menyumbang kontribusi terhadap PDB sebesar $13,59 \%$ dengan pertumbuhan $7,1 \%$ (year on year/yoy).

Sektor pertanian Indonesia memiliki potensi yang besar untuk dapat dikembangkan dalam menunjang kebutuhan bagi masyarakat Indonesia. Ubi kayu atau ketela pohon (Manihot utilisima atau Manihot esculenta crantz) merupakan pohonan tahunan tropika dan subtropika dari keluarga Euphorbiaceae yang sudah banyak ditanam hampir di seluruh dunia. Ubikayu tersebar di beberapa benua antara lain di benua Asia yaitu di Thailand, Vietnam, India, dan China, di Benua Afrika yaitu di Nigeria, Kongo, Ghana, Mozambik, Angola, dan Uganda, dan di Benua Amerika produksi ubikayu terbesar yaitu berasal dari Brazil (Gardjito, 2013). Tanaman ini masuk ke Indonesia pada tahun 1852 melalui Kebun Raya Bogor, dan kemudian tersebar ke seluruh wilayah Nusantara pada saat Indonesia kekurangan 
pangan, yaitu sekitar tahun 1914-1918 (Purwono, 2009).

Produksi ubikayu di Indonesia dapat diperoleh melalui hubungan perbandingan lurus antara luas panen dan produktivitas itu sendiri. Berdasarkan data yang dihimpun oleh Badan Pusat Statistik (2017), luas panen ubikayu cenderung menurun sedangkan produktivitas cenderung meningkat. Karena produksi ubikayu merupakan perkalian antara luas panen dan produktivitas, maka produksi ubikayu di Indonesia mengalami fluktuasi namun dapat dikatakan memiliki tren yang meningkat.

Provinsi Lampung merupakan salah satu provinsi penghasil komoditi utama ubikayu. Produksi ubikayu di Provinsi Lampung pada tahun 2015 mencapai 8,03 juta ton umbi basah. Produksi ini menyuplai sepertiga produksi ubi kayu nasional dari total ubikayu nasional sebesar 22,91 juta ton umbi basah. Perkembangan produksi ubikayu pada tahun 2014 hingga 2018 menunjukkan tren yang meningkat. Hal ini didukung oleh luas panen dan produktivitas ubikayu yaitu selama pada tahun tersebut yang masih tetap memberikan tren yang meningkat. Penurunan produksi ubikayu terjadi pada tahun 2018 yaitu sebesar 806,32 ribu ton umbi basah dibandingkan dengan tahun 2017. Proses tersebut disebabkan berkurangnya luas panen meskipun produktivitas meningkat. Proses penurunan produksi ubikayu masih tetap terjadi hingga pada tahun 2017.

Sentra produksi Ubi Kayu di Provinsi Lampung terletak di Kabupaten Lampung Barat. Produksi ubikayu di Kabupaten Lampung Barat pada tahun 2015 mencapai 3,37 juta ton umbi basah atau setara dengan 40,20 persen dari total produksi ubikayu Provinsi Lampung. Kemudian diikuti Kabupaten Lampung Utara sebagai produksi ubikayu terbesar kedua dengan menghasilkan 1,36 juta ton, diikuti Kabupaten Lampung Timur menghasilkan
1,24 juta ton, Tulang Bawang Barat 1,06 juta ton dan Tulang Bawang 0,53 juta ton. Kelima kabupaten tersebut mampu memproduksi ubikayu 90,10 persen dari total produksi ubikayu Provinsi Lampung (BPS, 2019).

Menurut Food and Agriculture Organization (FAO), ubikayu dengan kadar $50 \mathrm{mg} / \mathrm{kg}$ masih aman untuk dikonsumsi manusia (Winarno, 2004). Kadar HCN dapat dikurangi / diperkecil (detoksifikasi sianida) dengan cara perendaman, ekstraksi pati dalam air, pencucian, perebusan, fermentasi, pemanasan, pengukusan, pengeringan dan penggorengan (Coursey, 1973). Ubikayu dapat dimanfaatkan salah satu nya dijadikan tepung. Tepung ubikayu dapat mensubstitusi tepung terigu sebanyak 15-30\%, tergantung dari produk olahan yang akan dihasilkan. Menurut Budijono et al (2003), tepung ubikayu dapat mensubstitusi $50-100 \%$ tepung terigu, 4060\% tapioka, dan $75-100 \%$ maizena pada aneka kue kering. Arief (2004), menambahkan bahwa tepung ubikayu dapat mensubstitusi 50\% tepung ketan pada pembuatan kue dengan rasa, warna, aroma, dan tekstur kue yang masih disukai oleh konsumen dan 20-75\% substitusi tepung terigu pada beberapa produk kue. Selain itu beberapa tepung ubi kayu juga sudah mulai dimodifikasi dengan nama yang berbeda. Sesungguhnya, karakteristik fisika dan kimia tepung tersebut relatif sama, hanya proses fermentasi dan starter yang digunakan sedikit berbeda dan diberi nama sesuai dengan orang atau instansi yang memproduksi tepung tersebut.

Salah satu modifikasi tepung ubikayu yang memiliki nilai jual yang cukup tinggi adalah tepung Mocaf. Tepung Mocaf merupakan singkatan dari (Modified Cassava Flour). Sederhananya adalah tepung dari singkong yang telah dimodifikasi dengan cara difermentasi. Dengan cara ini, aroma singkong menjadi hilang. Keunggulan dari tepung mocaf 
adalah kandungan kalsium dalam tepung mocaf yang lebih tinggi dari gandum maupun padi. Selain itu, tepung ini juga lebih mudah dicerna oleh tubuh dari pada tepung terigu karena tidak mengandung asam sianida. Untuk membuat tepung mocaf, singkong yang telah dibersihkan kemudian dicacah hingga berbentuk pipih. Setelah itu, hasil cacahan direndam di dalam bak yang berisi air dan senyawa aktif sekitar 3 hari. Kemudian dilanjutkan dengan penggaraman lalu penjemuran selama 2 hari. Yang terakhir adalah menggiling hasil penjemuran menjadi tepung. Menurut (Iskandar 2010 dalam Trubus 2010).

Mocaf (Modified Cassava Flour) adalah tepung ubikayu yang dihasilkan dari proses fermentasi menggunakan mikroba (bioaktivator). Bioaktivator yang digunakan berupa kumpulan beberapa spesies mikroba, antara lain Lactobacillus spp (bakteri pelarut fosfat), Azetobacter spp, dan ragi. Mikroba tersebut menghasilkan asam laktat sebagai hasil fermentasi pati dan enzim selulase yang berperan dalam meningkatkan proses dekomposisi atau pemecahan lignin dan selulosa. Tepung yang dihasilkan disebut juga modifikasi tepung singkong atau "motes". Proses fermentasi mocaf biasanya berlangsung selama 7-8 jam dengan melibatkan tiga kali penambahan bakteri atau enzim. Enzim pertama berfungsi menetralisir air agar sesuai bagi bakteri untuk tumbuh dan berkembang biak, enzim kedua berfungsi merombak pati dan dinding sel ubikayu, dan enzim ketiga bertugas menghentikan fermentasi.

Menurut (Haryadi 2010 dalam Trubus 2010), percepatan fermentasi menjadi 1 jam karena adanya aktivitas enzim selulase. Enzim tersebut berperan mendegradasi selulosa yang membungkus molekul pati. Kombinasi asam laktat dan enzim selulase memungkinkan proses fermentasi terjadi dalam waktu 1 jam. Fermentasi menggunakan asam laktat tidak hanya menghasilkan mocaf yang bertekstur halus yang disebabkan oleh hancurnya selulosa, tapi juga menyebabkan aroma khas ubikayu hilang dan warna tepung menjadi lebih putih. Sementara menurut Subagio (2007), proses fermentasi mocaf selama 1 jam tidak mungkin, karena mikroba yang dipergunakan tak bisa langsung bekerja mendegradasi selulosa. Mikroba biasanya akan mulai bekerja setelah 3-4 jam diaplikasikan ke media. Tepung ubikayu yang dihasilkanpun mutunya kurang optimal, karena serat belum terdegradasi sempurna oleh mikroba, akibatnya ketika digiling serat ubikayu masih banyak yang panjang dan kasar. Namun waktu fermentasi yang singkat ini menyebabkan rendemen meningkat menjadi $40 \%$ dari rendemen sebelumnya yang hanya berkisar antara 30-33\%.

Desa Kenanga adalah salah satu sentra pembuatan tepung mocaf, mayoritas masyarakat yang ada di desa Kenanga bekerja sebagai petani. Para petani di desa Kenanga memanfaatkan hasil panen mereka terutama ubi kayu/singkong sebagai alat untuk mendapatkan keuntungan. Ubi kayu/singkong dari hasil panen mereka dimodifikasi menjadi tepung Mocaf. Tepung Mocaf sendiri memiliki tingkat harga yang cukup tinggi di bandingkan tepung tapioka. Kandungan yang terdapat pada tepung Mocaf pun sangat cukup baik dibandingkan tepung tapioka. Masalah yang dihadapi di desa Kenanga Kabupaten Lampung Barat adalah tingkat pemasaran dan juga tingkat harga yang sering berfluktuatif kadang menjadi pertimbangan petani yang ada di desa Kenanga untuk melakukan produksi tepung Mocaf.

Berdasarkan uraian tersebut, peneliti tertarik melakukan penelitian dengan judul: "Analisis Kelayakan Pengembangan Usaha Tepung Mocaf Dalam Meningkatkan Taraf Hidup Masyarakat 


\section{Di Desa Kenangan Liwa Lampung Barat.”}

\section{KAJIAN TEORI}

\section{Pengertian Pengembangan Usaha}

Pengembangan usaha adalah tugas dan proses persiapan analitis tentang peluang pertumbuhan potensial, dukungan dan pemantauan pelaksanaan peluang pertumbuhan usaha, tetapi tidak termasuk keputusan tentang strategi dan implementasi dari peluang pertumbuhan usaha.

Sedangkan untuk usaha yang berskala besar dan mapan, terutama di bidang teknologi industri yang terkait "Pengembangan usaha" istilah yang sering mengacu pada pengaturan dan mengelola hubungan strategis dan aliansi dengan yang lain, perusahaan pihak ketiga.

Dalam hal ini perusahaan dapat memanfaatkan satu sama lain keahlian, teknologi atau kekayaan intelektual untuk memperluas kapasitas mereka untuk mengidentifikasi, meneliti, menganalisis dan membawa ke pasar bisnis baru dan produk baru, pengembangan bisnis berfokus pada implementasi dari rencana bisnis strategis melalui ekuitas pembiayaan, akuisisi / divestasi teknologi, produk, dan lain - lain.

Jadi, pengembangan usaha memiliki tingkat yang berbeda. Level atau tingkatan tersebut menjadi produk, komersial dan korporasi. Berikut ini akan dijelaskan tentang tingkatan - tingkatan yang ada pada pengembangan usaha yaitu :

1. Tingkat Produk

Pada level produk pengembangan usaha berarti mengembangkan produk atau teknologi baru. Meskipun tingkat pengembangan dapat berbeda dari perusahaan ke perusahaan.

\section{Tingkat Komersial}

Dalam contoh bentuk pengembangan usaha di tingkat komersial berarti prospeksi murni et Dur. Ini berarti berburu pelanggan baru di segmen pasar yang baru. Dengan demikian pekerjaan ini memerlukan individu secara psikologis yang kuat dan yang sangat didorong mampu menangani banyak masalah. Tingkat berikutnya dari pengembangan usaha komersial adalah saluran atau setup organisasi penjualan. Saluran atau organisasi penjualan dapat terdiri dari mitra, agen seperti, distributor, pemegang lisensi,franchisee, atau cabang anda sendiri nasional atau internasional. Tingkat pengembangan usaha komersial adalah tingkat rantai nilai. Pada pengembangan rantai nilai tingkat usaha adalah tentang mengembangkan penawaran produk secara keseluruhan. Anda akan menemukan jenis pengembangan usaha / bisnis di perusahaan- perusahaan teknologi yang telah mengembangkan platform yang harus diintegrasikan atau dikombinasikan dengan teknologi lain atau platform untuk membentuk seluruh produk. Sebuah seluruh produk umumnya terdiri dari beberapa teknologi untuk membuatnya menjadi hidup. Sebuah teknologi pada umumnya tidak dikembangkan oleh satu perusahaan tapi bersumber dari orang lain yang bertujuan untuk menghemat waktu dalam proses usaha.

\section{Tingkat Korporasi}

Organisasi harus memutuskan apakah akan membuat atau membeli kompetensi organisasi tertentu kita memasuki bidang pengembangan bisnis perusahaan . Fokusnya adalah bukan pada produk maupun komersial tingkat tetapi pada korporasi tingkatan usaha. Pada intinya tingkat pengembangan usaha ini adalah tentang merger \& akuisisi (M \& A), usaha patungan (JV), saham langsung 
investasi (DEI) dan aliansi strategis. Ini berkaitan dengan analisa bisnis portofolio, keuangan perusahaan, hukum kontrak, hukum pajak, hukum sosial, anti kepercayaan hukum, manajemen perubahan, dan manajemen budaya.

\section{Kandungan Singkong dan Manfaat Singkong}

Singkong memiliki beberapa nama seperti ketela pohon atau umbi kayu. Ketela pohon, ubi kayu, atau singkong memiliki nama latin Manihot utilissima dari suku Euphorbiaceae. Singkong adalah tumbuhan yang dapat hidup dimana saja, cara menanamnya mudah yaitu cukup dengan menancapkan bonggol (Jawa) ketanah, menancapkannya jangan sampai keliru yaa, mata pohon singkong menghadap ke atas.

Singkong juga mempunyai nama yang berbeda-beda berdasarkan tempatnya, antara lain adalah: Bahasa Indonesia (Singkong, Ketela pohon), Sumatera (ubi kayu), Jawa (Pohong, Budin), Sunda (Sampek, boled), Papua (Kaspe), Inggris (Cassava, tapioca plant), Pilipina (Kamoteng kahoy), Prancis (Manioc). Singkong dapat menjadi bahan baku industri rumah tangga, sebagai bahan baku banyak makanan dan kue-kue tradisional seperti cenil, tiwul, keripik, lemet, getuk, dll. Selain itu dapat juga di gunakan sebagai bahan baku industri seperti sebagai bahan untuk membuat pati tapioka, tepung tapioka, bioetanol, dan lain-lain.

Berikut ini adalah kandungan gizi yang bterdapat pada singkong dalam setiap 100 gr nya:
a. Kalori $121 \mathrm{kal}$
b. Air 62,50 gram
c. Fosfor 40,00 gram
d. Karbohidrat 34,00 gram
e. Kalsium 33,00 miligram
f. Vitamin C 30,00 miligram
g. Protein 1,20 gram
h. Besi 0,70 miligram

i. Lemak 0,30 gram

j. Vitamin B1 0,01 miligram

Manfaat Singkong untuk Kesehatan:

1. Mengatasi rematik cara mengobati: Ambil lima lembar daun singkong, 15 gram jahe merah, dan kapur sirih secukupnya, dihaluskan dan ditambahkan air secukupnya. Setelah diaduk, ramuan dioleskan pada bagian tubuh yang sakit. Pada pemakaian dalam, 100 gram batang singkong, satu batang sereh, dan 15 gram jahe direbus dengan $1.000 \mathrm{cc}$ air hingga tersisa 400 cc. Lalu, disaring dan diminum airnya sebanyak 200 cc. Lakukan dua kali sehari.

2. Mengatasi sakit kepala cara mengobati: Ambildaun singkong ditumbuk lalu digunakan untuk kompres. Sebagai obat demam, 60 gram batang pohon singkong, 30 gram jali yang telah direndam hingga lembut direbus dengan $800 \mathrm{cc}$ air hingga tersisa 400 cc. Ramuan disaring dan diminum airnya sebanyak 200 cc. Lakukan dua kali sehari.

3. Mengatasi luka bernanah cara mengobati: Ambil batang singkong segar ditumbuk lalu ditempelkan pada bagian tubuh yang sakit. Untuk luka garukan, singkong diparut lalu ditempelkan pada bagian yang sakit dan diperban.

4. Obat luka karena terkena benda panas cara mengobati: Ambil singkong diparut lalu diperas. Airnya didiamkan beberapa saat hingga patinya mengendap, lalu patinya dioleskan pada bagian yang luka.

5. Mengatasi diare cara mengobati: Ambil tujuh lembar daun singkong direbus dengan $800 \mathrm{cc}$ air hingga tersisa $400 \mathrm{cc}$. Lalu disaring dan diminum airnya sebanyak 200 cc. Lakukan dua kali sehari. 
6. Obat cacingan cara mengobati: Ambil 60 gram kulit batang singkong dan 30 gram daun ketepeng cina direbus dengan $600 \mathrm{cc}$ air hingga tersisa $300 \mathrm{cc}$. Lalu disaring dan diminum airnya menjelang tidur. Mengatasi beri-beri, 200 gram daun singkong dimakan sebagai lalap.

7. Untuk meningkatkan stamina cara mengobati: Ambil 100 gram singkong, 25 gram kencur, dan lima butir angco (kurma merah, beli di toko obat/makanan china) yang telah dibuang bijinya, diblender dengan menambahkan air secukupnya. Lalu tambahkan madu dan diminum

\section{Campuran Tepung Mocaf}

Sebenarnya ada banyak cara untuk membuat tepung mocaf atau tepung singkong, dari yang melibatkan enzim sampai cara sederhana yang menggunakan teknik mekanis. Berikut ini adalah cara-cara membuat tepung mocaf dengan mudah :

1. Kupas singkong dari kulitnya.

2. Bersihkan singkong menggunakan air bersih dan pastikan lendir yang berada diantara kulit dan daging umbi juga bersih. Pembersihan bisa dilakukan dengan cara menyikat permukaan umbi singkong.

3. Potong-potong singkong setipis mungkin, ini dimaksudkan untuk mempercepat proses pengeringan nantinya.

4. Rendam singkong dalam air bersih selama minimal 2 hari 2 malam, proses ini akan menghasilkan endapan tepung tapioka. Pisahkan tepung dan keringkan untuk keperluan berikutnya.

5. Selama proses perendaman, air harus diganti maksimal 24 jam sekali atau lebih bagus 12 jam sekali, jika tidak hasil tepung akan menyisakan bau seperti bau singkong yang busuk terendam.
6. Angkat singkong dari rendaman dan jemur hingga benar-benar kering dengan kadar air kurang lebih 10\%, cirinya singkong mulai lapuk/rapuh.

7. Saatnya proses penggilingan, jika tidak ada alat giling kita juga bisa menumbuknya menggunakan lumpang hanya saja prosesnya lebih lama.

8. Ayak singkong hasil tumbukan dengan ayakan tepung, alat ini banyak dijual di toko tempat penjualan perkakas rumah tangga. Sisa ayakan dapat ditumbuk kembali sampai benar-benar halus.

9. Satukan tepung hasil ayakan dengan tepung tapioka yang diperoleh dari hasil perendaman dan jemur kembali sampai benar-benar kering.

10. Tepung MOCAF sudah siap digunakan, jika tidak digunakan secara langsung simpan pada wadah/plastik yang tertutup rapat.

\section{METODE PENELITIAN}

\section{Objek Penelitian}

Objek Penelitian dalam penelitian ini adalah masyarakat Desa Kenanga Liwa Kabupaten Lampung Barat penelitian ini dilakukan dan bulan Mei sampai dengan Agustus 2019.

\section{Metode dan Teknik Pengumpulan Data}

Dalam penelitian ini jenis data yang diperlakukan adalah :

a. Data Primer

Data primer merupakan data dasar yang akan diperoleh langsung tanpa perantara orang atau lembaga lain sebagai pihak ketiga. Data primer ini diperoleh dengan wawancara melalui responden dengan menggunakan daftar pertanyaan.

b. Data Sekunder

Data skunder merupakan data yang diperoleh melalui orang lain yang 
berhubungan dengan permasalahan yang dipecahkan. Data sekunder ini diperoleh melalui cara studi dokumenter yaitu mengumpulkan dan mempelajari brosurbrosur serta dokumen organisasi.

Adapun teknik yang digunakan dalam pengumpulan data adalah dengan :

1. Observasi, yaitu mengadakan survey atau pengamatan langsung kelokasi penelitian.

2. Interview atau wawancara, yaitu mengadakan tanya jawab langsung dengan objek penelitian.

3. Dokumentasi, yaitu mengumpulkan dan mencatat dokumentasi yang relevan.

4. Kuisioner, yaitu membuat pertanyaan yang berhubungan dengan varibael penelitian.

\section{Sampel dan Populasi}

Teknik sampel yang digunakan dalam penelitian ini adalah teknik populasi yaitu dengan mengambil keseluruhan dari objek yang akan diteliti. Disamping itu cara pengambilan sample dapat digunakan ketentuan menurut para ahli seperti Suharsimi Arikunto menyatakan bahwa apabila subyek kurang dari 100 lebih baik diambil semua sehingga penelitiannya merupakan penelitian populasi, selanjutnya jika subyek kurang dari 100 adapt diambil sample antara $10 \%-15 \%$ atau 20\% - 25\% (Suharsimi Arikonto, 2006). Dalam penelitian ini yang dijadikan sampel oleh penulis adalah sebanyak 40 orang responden, yang berasal dari masyarakat Desa Kenangan, Liwa, Kabupaten Lampung Barat.

\section{Metode Analisis Data}

Analisa yang digunakan untuk menjelaskan analisis kualitatif dengan menggunakan pendekatan teoritis manajemen sumber daya manusia, khususnya teori mengenai kelayakan pengembangan usaha tepung mocaf dalam meningkatkan taraf hidup masyarakat.

Penugasan adalah suatu kasus khusus dan masalah linear programing, penyelesaian persoalan ini akan lebih efisien dengan menggunakan metode Hungarian. Dalam metode ini diberikan beberapa altematif penugasan tenaga kerja yang disusun secara vertikal, dan kolomkolom pekerjaan yang disusun secara honisontal.

Langkah- langkah pengoptimalan dalam metode Hungarian adalah sebagai berikut:

a) Matrik Penurunan biaya (Reduced Cost Matrix), yaitu mengurangi angka pada masing-masing baris dengan angka yang paling kecil pada baris tersebut.

b) Matrik Kesempatan Biaya (Opportunity Cost Matrix), yaitu mengurangi angka pada setiap kolom dengan angka yang paling kecil di antara angka-angka yang terdapat pada kolom yang bersangkutan.

c) Matrik Pengujian Keoptimalan (Test For Optitnality Matrix), yaitu memberi tanda garis pada kolom dan bans yang memiliki angka nol paling banyak. Apabila jumlah garis sama dengan jumlah baris atau kolom, maka matrik sudah optimal.

d) Apabila belum optimal, maka angkaangka di luar garis dikurangi angka yang paling kecil di antara angka-angka tersebut dan menambahkannya pada angka yang terletak di perpotongan garis-garis tersebut.

e) Setelah optimal maka pekerja yang memiliki satu-satunya angka nol, dialokasikan pada tenaga kerja yang bersangkutan (Agus Ahyari, 2004).

Asumsi-asumsi yang digunakan :

1. Jumlah tenaga kerja sama dengan jumlah mesin/pekerja yang akan dialokasikan 
2. Setiap pekerja dapat melakukan pekerjaan/menggunakan mesin yang ada

3. Tidak menghitung biaya lembur

4. Tidak terjadi perputaran tenaga kerja (Turn Over).

\section{HASIL DAN PEMBAHASAN}

Analisis kelayakan usaha tanpa diskonto digunakan untuk menganalisis usaha secara finansial dalam jangka pendek sehingga pada analisis ini tidak terlalu mementingkan nilai uang yang berubah dalam proses analisisnya.

Pada analisis ini laporan rugi laba yang digunakan adalah laporan rugi usaha Tepung Mocaf (Modified Cassava Flour) di Desa Indraloka II Kecamatan Way Kenangan Kabupaten Tulang Bawang selama satu periode ( 6 bulan ) pada tahun 2019. Net Present Value adalah kriteria investasi yang banyak digunakan dalam mengukur apakah suatu proyek feasible atau tidak. Net Present Value yaitu selisih antara Present Value dari investasi dengan nilai sekarang dari penerimaan-penerimaan kas bersih (aliran kas operasional maupun aliran kas terminal) di masa yang akan datang.

Keputusan :

Jika IRR > Tingkat bunga maka usaha layak untuk dijalankan.

Jika IRR < Tingkat bunga maka usaha tidak layak untuk dijalankan.

Jika Gross B/C > 1, maka usaha layak untuk dijalankan

Jika Gross B/C < 1, maka usaha tidak layak untuk dijalankan

Jika Gross $\mathrm{B} / \mathrm{C}=1$ (satu) berarti proyek dalam keadaan BEP

Payback Period merupakan jangka waktu/lamanya investasi dari suatu proyek berdasarkan keuntungan yang diperoleh tiap-tiap tahun. Payback Period hanya untuk mengetahui jangka waktu kembalinya investasi tanpa memperhatikan besarnya benefit atau keuntungan dari suatu proyek/usaha.

Analisis sensivitas merupakan analisis yang dilakukan untuk mengetahui akibat dari perubahan parameter-parameter produksi terhadap perubahan kinerja sistem produksi dalam menghasilkan keuntungan. Dengan melakukan analisis sensitivitas maka akibat yang mungkin terjadi dari perubahan-perubahan tersebut dapat diketahui dan diantisipasi sebelumnya. Analisis sensitivitas dilakukan dengan menghitung IRR, NPV, $B / C$ ratio, dan payback period pada beberapa skenario perubahan yang mungkin terjadi. Hasil yang harus diperoleh dari analisis switching value yaitu $\mathrm{NPV}=0$ dan $\mathrm{Net} \mathrm{B} / \mathrm{C}=1$.

Pendapatan diperoleh dari selisih antara penerimaan dan biaya total selama sebulan. Penerimaan adalah perkalian antara produksi yang diperoleh dengan harga jual. Biaya usaha diklasifikasikan menjadi dua yaitu biaya tetap (Fixed Cost) dan Biaya tidak tetap (Variable Cost). Dalam sekali proses produksi tepung mocaf di kelompok Sungai Suci dihasilkan $86 \mathrm{~kg}$ tepung mocaf dengan harga jual Rp. 7.500,$/ \mathrm{kg}$, sehingga penerimaan berjumlah Rp.645.000, -. Biaya tidak tetap yang dikeluarkan sebesar Rp. 340.000,- untuk pembelian bahan baku ubi kayu, starter bimo $\mathrm{CF}$, bahan bakar, kemasan, tenaga kerja dan biaya lainnya.

Selisih antara penerimaan dan biaya sebesar Rp. 305.000,- merupakan keuntungan usaha dengan $\mathrm{R} / \mathrm{C}$ rasio 1,90 dengan arti bahwa setiap pengeluaran dalam proses pengolahan sebesar satu rupiah akan diperoleh penerimaan sebesar 1,90 rupiah. Dengan demikian maka dapat dikatakan bahwa usaha pengolahan tepung mocaf layak untuk dikembangkan (R/C rasio $>1)$.

Hasil perhitungan nilai tambah dengan asumsi bahan baku ubi kayu merupakan hasil panen di lahan petani sendiri, menunjukkan bahwa dengan melibatkan 
jumlah tenaga kerja sebanyak 3 orang, pengolahan ubi kayu sebanyak $250 \mathrm{~kg}$ dapat menghasilkan $86 \mathrm{~kg}$ tepung mocaf. Nilai output yang dihasilkan dari pengolahan ubi kayu menjadi tepung mocaf adalah sebesar Rp. 2550,-/kg. Nilai output ini diperoleh dari perkalian antara faktor konversi sebesar 0,34 dengan harga output sebesar Rp. 7.500,-. Hasil analisis nilai tambah tepung mocaf selengkapnya dapat dilihat pada Tabel 1 .

Tabel 1. Hasil Analisis Nilai Tambah Tepung mocaf

\begin{tabular}{|c|c|}
\hline Variabel & Kode \\
\hline \multicolumn{2}{|l|}{ I. Output, Input dan Harga } \\
\hline 1. Output $(\mathrm{Kg})$ & 86 \\
\hline 2. Input (Kg) & 250 \\
\hline 3. Tenaga Kerja (HOK) & 3 \\
\hline 4. Faktor Konversi & 0,34 \\
\hline 5. Koefisien Tenaga Kerja (HOK) & 0,012 \\
\hline 6. Harga Output $(\mathrm{Rp} / \mathrm{Kg})$ & 7.500 \\
\hline 7. Upah Tenaga Kerja Langsung (Rp/HOK) & 30.000 \\
\hline \multicolumn{2}{|l|}{ II. Peneriman dan Keuntungan } \\
\hline 8. Harga Bahan Baku (Rp/Kg) & 800 \\
\hline 9. Sumbangan Input Lain $(\mathrm{Rp} / \mathrm{Kg})$ & 200 \\
\hline 10. Nilai Output $(\mathrm{Rp} / \mathrm{Kg})$ & 2.550 \\
\hline 11. a. Nilai Tambah $(\mathrm{Rp} / \mathrm{Kg})$ & 1.550 \\
\hline b. Rasio Nilai Tambah (\%) & 60,78 \\
\hline 12. a. Pendapatan Tenaga Kerja Langsung ( $\mathrm{Rp} / \mathrm{Kg})$ & 360 \\
\hline b. Pangsa Tenaga Kerja (\%) & 23,23 \\
\hline 13. a. Keuntungan $(\mathrm{Rp} / \mathrm{Kg})$ & 1.190 \\
\hline b. Tingkat Keuntungan (\%) & 76,77 \\
\hline \multicolumn{2}{|l|}{ III. Balas Jasa Pemilik Faktor-Faktor Produksi } \\
\hline 14. Marjin $(\mathrm{Rp} / \mathrm{Kg})$ & 1.750 \\
\hline a. PendapatanTenagaKerjaLangsung (\%) & 20,57 \\
\hline b. Sumbangan Input Lain $(\%)$ & 11,43 \\
\hline c. KeuntunganPemilik Perusahaan (\%) & 68 \\
\hline
\end{tabular}

Dari Tabel 1. dapat dilihat bahwa nilai tambah yang diperoleh dari pengolahan ubi kayu menjadi tepung mocafmampu meningkatkan nilai tambah ubi kayu sebesar Rp.1.550/kg dengan rasio nilai tambah sebesar $60,78 \%$. Dengan demikian terdapat peningkatan nilai tambah ubi kayu melalui penerapan teknologi pengolahan tepung mocaf. Hal ini sesuai dengan pendapat Hernanto (2003) bahwa penerapan teknologi akan berpengaruh terhadap biaya dan penerimaan
petani.Marjin yang diperoleh dari pengolahan tepung mocaf sebesar Rp. $1.750 / \mathrm{kg}$. Pendapatan tenaga kerja langsung terhadap marjin sebesar 20,57\%, sumbangan input lain sebesar $11,43 \%$ dan keuntungan bagi pemilik modal/perusahaan sebesar $68 \%$.

\section{KESIMPULAN DAN SARAN}

\section{Kesimpulan}

Dari pembahasan yang telah dikemukakan diatas, maka dapat disimpulkan sebagai berikut :

1. Penerimaan total yang diperoleh industri pengolahankelompok Sungai Sucidalammemproduksitepungmocafdal am sekali proses sebesarRp. 645.000,dengan

pendapatanbersihsebesarRp.305.000,-

.Dalam satu bulan dengan proses produksi sebanyak delapan kali, total penerimaan sebesar Rp. 5.160.000,dengan biaya produksi sebesar $\mathrm{Rp}$. 2.720.000,- keuntungan yang dihasilkan sebesar 2.440.000,-.

2. Agroindustri pengolahan tepung mocaf sangat layak untuk diusahakan, karena hasil analisis finansial menunjukkan nilai RC Ratio 1,9, sedangkan besarnya nilai tambah pengolahan tepung mocaf yang diperoleh sebesarRp. 1.550, $/ \mathrm{kg}$. Hal ini menunjukan bahwa setiap satu kilogram ubi kayu segar setelah mengalami proses produksi mampu memberikan nilai tambah sebesar Rp.1550,-.

\section{Saran}

Sedangkan saran yang dapat penulis sampaikan dalam penelitian ini adalah sebagai berikut :

1. Hendaknya pemerintah daerah lebih memperhatikan pengembangan usaha tepung mocaf di Desa Kenanga Liwa 
Kabupaten Lampung Barat agar taraf hidup masyarakat setempat dapat menjadi lebih baik.

2. Hendaknya pihak pemerintah dan swasta dapat memberikan modal / pinjaman agar dapat mengembangkan usaha tepung mocaf di daerah Desa Kenanga Liwa Kabupaten Lampung Barat.

\section{DAFTAR PUSTAKA}

Almatsier, Sunita. 2009. Prinsip Dasar Ilmu Gizi. Jakarta: PT.Gramedia Pustaka Utama.

Badan Pusat Stastistika (BPS) Nasional. 2017. Dalam Angka.

Badan Pusat Stastistika (BPS) Kabupaten Lampung. 2017. Lampung Dalam Angka.

Dimyati, H., Nurjaman, K. 2014,.Manajemen Proyek, Cetakan Pertama. Bandung: Pustaka Setia.

Gittinger. 1986. Evaluasi Proyek. Jakarta: Bhineka cipta.

Husnan, S. dan Suwarsono, M. 2000. Studi Kelayakan Proyek, Edisi ke-4. Yogyakarta: Unit Penerbit dan Percetakan.

Ibrahim, Yacob. 2003. Studi Kelayakan Bisnis. Edisi Revisi. Jakarta: Rineka Cipta.

Kadariah, Karlina L, Gray C. 1999. Pengantar Evaluasi Proyek. Jakarta: UI Press.

Kasmir dan Jakfar. 2003. Studi Kelayakan Bisnis. Jakarta: Kencana.

Lihan, Irham. 2009. Studi Kelayakan Bisnis. Jakarta: Poliyama Widyapustaka.
Samuelson, Paul A dan Nordhaus, William D. 2001. Ilmu Makro Ekonomi. Jakarta: PT. Media Edukasi.

Sunariyah. 2004. Pengantar Pengetahuan Pasar Modal. Edisi Kelima. Bandung: CV Alfabeta.

Suratiyah, Ken. 2008. Ilmu Usaha Tani. Jakarta: Penebar Swadaya.

Sosrosoedirdjo, R.S. 1993. Bercocok Tanam Ketela Pohon. Jakarta:CV.Yasaguna.

Umar, Husein. 2005. Studi Kelayakan Bisnis, Manajemen, Metode dan Kasus. Jakarta: PT. Gramedia Pustaka Utama.

Wiajaya, Toni. 2013. Metode penelitian ekonomi dan bisnis Teori dan praktek. Yogyakarta: Graha ilmu. 